\title{
Article \\ The Fungicide Chlorothalonil Changes the Amphibian Skin Microbiome: A Potential Factor Disrupting a Host Disease-Protective Trait
}

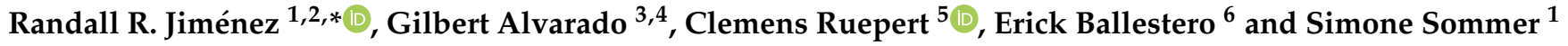 \\ 1 Institute of Evolutionary Ecology and Conservation Genomics, University of Ulm, 89069 Ulm, Germany; \\ simone.sommer@uni-ulm.de \\ 2 Center for Conservation Genomics, Smithsonian National Zoological Park and Conservation \\ Biology Institute, Washington, DC 20008, USA \\ 3 Laboratory of Comparative Wildlife Pathology, School of Veterinary Medicine and Animal Sciences, \\ University of São Paulo, São Paulo 05508-060, Brazil; gilbert.alvarado@ucr.ac.cr \\ 4 Laboratory of Experimental and Comparative Pathology (LAPECOM), Biology School, \\ University of Costa Rica, San José 2060, Costa Rica \\ 5 Instituto Regional de Estudios en Sustancias Toxicas (IRET), Universidad Nacional, Heredia 3000, Costa Rica; \\ clemens.ruepert@una.cr \\ 6 Escuela de Ciencias Biológicas, Universidad Nacional, Heredia 3000, Costa Rica; eballestero87@gmail.com \\ * Correspondence: randall87@gmail.com or jimenezquirosr@si.edu
}

check for updates

Citation: Jiménez, R.R.; Alvarado, G.; Ruepert, C.; Ballestero, E.; Sommer, S. The Fungicide Chlorothalonil Changes the Amphibian Skin Microbiome: A Potential Factor Disrupting a Host Disease-Protective Trait. Appl. Microbiol. 2021, 1, 26-37. https://doi.org/10.3390/ applmicrobiol1010004

Academic Editor: Bong-Soo Kim

Received: 23 February 2021

Accepted: 8 April 2021

Published: 10 April 2021

Publisher's Note: MDPI stays neutral with regard to jurisdictional claims in published maps and institutional affiliations.

Copyright: (c) 2021 by the authors. Licensee MDPI, Basel, Switzerland. This article is an open access article distributed under the terms and conditions of the Creative Commons Attribution (CC BY) license (https:// creativecommons.org/licenses/by/ $4.0 /)$.

\begin{abstract}
The skin microbiome is an important part of amphibian immune defenses and protects against pathogens such as the chytrid fungus Batrachochytrium dendrobatidis (Bd), which causes the skin disease chytridiomycosis. Alteration of the microbiome by anthropogenic factors, like pesticides, can impact this protective trait, disrupting its functionality. Chlorothalonil is a widely used fungicide that has been recognized as having an impact on amphibians, but so far, no studies have investigated its effects on amphibian microbial communities. In the present study, we used the amphibian Lithobates vibicarius from the montane forest of Costa Rica, which now appears to persist despite ongoing Bd-exposure, as an experimental model organism. We used 16S rRNA amplicon sequencing to investigate the effect of chlorothalonil on tadpoles' skin microbiome. We found that exposure to chlorothalonil changes bacterial community composition, with more significant changes at a higher concentration. We also found that a larger number of bacteria were reduced on tadpoles' skin when exposed to the higher concentration of chlorothalonil. We detected four presumed Bd-inhibitory bacteria being suppressed on tadpoles exposed to the fungicide. Our results suggest that exposure to a widely used fungicide could be impacting host-associated bacterial communities, potentially disrupting an amphibian protective trait against pathogens.
\end{abstract}

Keywords: chlorothalonil; pesticide; amphibian; skin microbiome; bacterial communities

\section{Introduction}

Amphibians around the world are increasingly threatened by diseases caused by fungi, viruses, bacteria, and parasites [1,2]. Particularly, the infectious skin disease, chytridiomycosis, is one of the main diseases impacting amphibian health $[3,4]$. This disease caused by the chytrid fungal pathogens Batrachochytrium dendrobatidis $(\mathrm{Bd})$ and B. salamandrivorans (Bsal) can cause mass die-offs in amphibian species $[5,6]$. The skin microbiome is considered one of the first lines of defense against pathogenic infections and can mediate disease susceptibility [7-9], suggesting it is an essential part of the amphibian's innate immune system. In amphibians, protection against pathogens has been linked to distinct characteristics of the skin bacterial communities, such as bacterial species richness, microbial community assemblage, and the presence and abundance of members in the bacterial communities capable of producing metabolites that suppress pathogen infections [10-13]. In addition, 
in healthy organisms, pathogenic and symbiotic microbiota can coexist without problems. However, if there is a disturbance in the current balance of the microbial community (called dysbiosis) caused by certain stress factors, it can impair normal microbial interactions and make the host more susceptible to diseases associated with pathogens [14].

Anthropogenic factors, such as pesticides, can cause dysbiosis, which can result in decreased protection against pathogens in their hosts [15-17]. The impact that pesticides can have on amphibian microbial communities, particularly fungicides, is a growing concern because of the increased use of these chemicals in agricultural practices and because many ecosystems are contaminated with these pollutants $[18,19]$. In agricultural environments, fungicides are widely used to control pathogenic fungi that threaten fruits and vegetables, and fungicides make up more than $35 \%$ of the pesticide market share worldwide [19]. There is evidence that pesticides, such as fungicides, have the potential to alter the structure and potential functionality of the microbiota of distinct taxa (e.g., fungicides, like chlorothalonil, perturbs honey bee gut microbiota) [20,21]. Fungicides may have a broad spectrum of direct and indirect actions on microbial communities. For example, they could be directly toxic to fungi and bacteria and/or they could favor the survival of bacteria because the death they cause to fungi indirectly increases the amount of nutrients available to the bacteria $[22,23]$. In soil environments, the fungicide chlorothalonil stimulates the growth of heterotrophic bacteria and actinobacteria, while it inhibits fungi growth [23]. The influence of pesticides on the amphibian microbiome remains poorly understood [16]. Due to the link of the microbiome in host health maintenance and protection against pathogens, studies that investigate the effects of pesticides, especially fungicides, on the amphibian microbiome and its protective functionality are urgently needed [16].

Chlorothalonil is a broad-spectrum organochlorine fungicide. It is mainly used to control fungal diseases on a wide range of vegetables and fruit crops [24]. In the tropics, chlorothalonil is applied extensively for the prevention and treatment of many crop diseases. It is applied to crops by aerial and ground applications multiple times per season to the same crop [25]. In Costa Rica, it is used in several plantations, such as bananas, potatoes, pineapples, and melons [26]. The mechanism of action of chlorothalonil consists of binding and depleting cellular glutathione (GSH) and can also inhibit glycolysis by binding with glyceraldehyde 3-phosphate dehydrogenase (GAPDH), leading to cell death $[27,28]$. Chlorothalonil can be incorporated into aquatic environments through direct application, runoff, evaporation, and aerial transport. Chlorothalonil can even reach places far away from application areas and can accumulate dangerous concentrations, which can have severe impacts on nontarget organisms [18,29]. For instance, chlorothalonil has been found accumulating in the environment of some neotropical montane forests in Costa Rica where many amphibian populations declined and disappeared, and far away from the lowlands where this fungicide has been applied, indicating the occurrence of atmospheric transport and wet deposition of chlorothalonil at high elevations [18]. Further, water systems containing sediments with organic content can facilitate the transport and accumulation of this chemical after its introduction [29]. Indeed, residues of this fungicide have been found in wild amphibian tissues (e.g., liver) along with other pesticides, posing a potential risk to their health and survival $[30,31]$. In amphibians, chlorothalonil has been found to be highly toxic [32-34]. It can reduce survival, affect growth and development, impact corticosterone levels, cause immunosuppression, and change disease susceptibility [33-36]. Considerable efforts have been undertaken to elucidate the effects of chlorothalonil in amphibians. However, the impact of this fungicide on amphibian microbial communities has not been studied. Therefore, understanding how chlorothalonil affects microbial communities is urgently needed, especially for amphibians that persist with the pathogen Bd in small and isolated populations in areas where this fungicide can potentially be found.

Using tadpoles of the green-eyed frog (Lithobates vibicarius) as our model organism and 16S rRNA amplicon sequencing, we examined the influence of chlorothalonil on the skin bacterial communities. Lithobates vibicarius is a neotropical montane amphibian 
formerly common throughout the mountain ranges of Tilarán, Cordillera Central, and Talamanca in Costa Rica and western Panama [37]. This species suffered population declines and disappearances across its entire range in the late 1990s and was considered possibly extinct. Six years after disappearing, this species has been re-encountered at different sites in isolated populations in Costa Rica and is reproducing in high numbers [38]. The disease chytridiomycosis was one of the main drivers of declines for L. vibicarius, possibly in combination with habitat disturbance, pesticides, and climate change [38]. The skin bacterial community may provide protection against $\mathrm{Bd}$ in this species [39].

We hypothesized that exposure to chlorothalonil would change the skin bacterial communities of tadpoles. We predicted that tadpoles exposed to chlorothalonil would have different bacterial communities than those not exposed to chlorothalonil and that this change would be more emphasized at higher fungicide concentrations. Thus, we investigated changes in the relative abundance of members in the bacterial communities when exposed to varying fungicide concentrations. We identified the presence of putative Bd-inhibitory bacteria with differential abundance between treatments. The present study serves as a baseline to understand the effect of a toxic fungicide on the microbially mediated immune defenses of a montane tropical amphibian, as well as the potential risk faced by remaining populations of L. vibicarius in landscapes where chlorothalonil can potentially be present.

\section{Materials and Methods}

\subsection{Tadpole Collection and Maintenance}

In October 2017, we collected 80 tadpoles of L. vibicarius with similar developmental stage (Gosner stage 27-29), body size (mean \pm standard deviation (SD): $41.5 \pm 4.4 \mathrm{~mm}$ ). and weight $(0.71 \pm 0.19 \mathrm{~g})$ from a permanent lagoon in the Juan Castro Blanco National Park, Alajuela, Costa Rica. Due to the high abundance of tadpoles we observed in the lagoons of the Juan Castro Blanco National Park during our monitoring program, we concluded that the number of collected animals did not have an impact on this population. The study and ethical procedures were approved by National Commission for the Biodiversity Management of Costa Rica (R-057-2019-OT-CONAGEBIO) and the Ministry of Environment and Energy of Costa Rica-National System of Conservation Areas (SINAC-ACAHN-PI-R-010-2017).

We captured the animals with nets and placed them in sterile plastic trays containing pond water. Animals were transported to a laboratory at the University of Costa Rica to carry out the chlorothalonil exposure experiment. All tadpoles were placed in an aquarium with filtered water and acclimatized to laboratory conditions for 8 days before starting the experiment. We consider an 8-day acclimation period an adequate time to acclimatize both host and microbiome to experimental conditions previous to any manipulations $[40,41]$. We know that the amphibian skin microbiome can change under captive conditions [42]; therefore, all tadpoles were set up under the same conditions to maintain the same initial microbiome baseline between treatments and reduce any potential effect in the results.

\subsection{Chlorothalonil Exposure and Sampling}

Following the acclimation period, we conducted an 8-day exposure experiment to investigate the effect of chlorothalonil on the skin microbiome of tadpoles. We established four treatments, which consisted of a negative control (filtered water), a solvent control (SC; methanol), and two concentrations of chlorothalonil; low concentration $(1 \mu \mathrm{g} / \mathrm{L})$ and high concentration $(5 \mu \mathrm{g} / \mathrm{L})$ (nominal concentrations). In Costa Rica, chlorothalonil has been detected in the environment (e.g., soil, air, and water), and concentrations above $11 \mu \mathrm{g} / \mathrm{L}$ have been reported in water bodies [18,26,43]. In addition, the concentrations of chlorothalonil used in this experiment are similar to demonstrably nonlethal concentrations used in another study using a species of the same genus, Lithobates taylori (E. Ballestero, unpublished data). Therefore, the exposure levels were chosen to reflect conditions that the species may experience in the wild. We prepared chlorothalonil exposure solutions by 
adding an aliquot of a stock solution to the exposure medium (filtered water). Stock solution $(1061 \mu \mathrm{g} / \mathrm{mL})$ was prepared from $97.5 \%$ pure chlorothalonil standard (Dr. Ehrenstorfer, Germany) dissolved in HPLC-grade 99.97\% methanol (J.T. Baker, Phillipsburg, Unites States) and kept at $4{ }^{\circ} \mathrm{C}$. Aliquots were taken using a microvolume syringe (SGE Analytical science, Australia). The quantitative analyses of chlorothalonil were performed with solid-phase extraction (SPE) and gas chromatography-mass spectrometry (GC-MS) at the Instituto Regional de Estudios en Sustancias Tóxicas (IRET), Universidad Nacional, Costa Rica. The actual concentrations for the low-concentration and high-concentration treatments at the beginning of the experiment were $0.9 \mu \mathrm{g} / \mathrm{L}$ and $5.3 \mu \mathrm{g} / \mathrm{L}$, respectively. We did not detect chlorothalonil in water samples at the end of the experiment $(<0.1 \mu \mathrm{g} / \mathrm{L})$.

In water, the half-life of chlorothalonil ranges from 0.18 to 8 days [44]. The amount of methanol added in the solvent control was the same as that one used in the highest concentration of chlorothalonil. We measured temperature $\left({ }^{\circ} \mathrm{C}\right), \mathrm{pH}$, and dissolved oxygen $(\mathrm{mg} / \mathrm{L})$ during the experiment (Supplemental Data Table S1).

Our experimental unit was one randomly chosen tadpole in a $1 \mathrm{~L}$ glass jar containing $800 \mathrm{~mL}$ of filtered water. We established 20 replicates per treatment (Table S2). Tadpoles were randomly assigned to one of the experimental treatments. We fed animals ad libitum with organic Spirulina on Days 0, 3, and 6.

On Day 8, we collected skin bacterial samples (skin swabs) from each animal. Swabbing consisted of moving a sterile rayon-tipped swab (Peel Pouch DryswabTM Fine Tip) across the animal skin. The swabbing protocol consisted of 12 strokes on each side (along body and tail), 12 strokes on the dorsal surface of the body, and 12 strokes on the mouth. We placed swabs in sterile vials with $300 \mu \mathrm{L}$ of DNA/RNA Shield (Zymo Research). The tubes were transported to Ulm University, Germany, and stored at $-20{ }^{\circ} \mathrm{C}$ until DNA extractions and sequencing. We used tricaine methanesulfonate (MS222) to euthanize all tadpoles at the end of the experiment.

\subsection{DNA Extraction and $16 S$ rRNA Gene Amplicon Sequencing}

We extracted bacterial genomic DNA from swabs using the NucleoSpin Soil kit (Macherey-Nagel, Düren, Germany) following the manufacturer's protocol. We amplified the hypervariable $\mathrm{V} 4$ region of the $16 \mathrm{~S}$ rRNA gene using the primers $515 \mathrm{~F}$ ( $5^{\prime}$ GTGCCAGCMGCCGCGGTAA-3') and 806R (5'-GGACTACHVGGGTWTCTAAT-3'). We followed the Fluidigm scheme (Access Array System for Illumina Sequencing Systems, Fluidigm Corporation), in which PCR and barcoding occur simultaneously. The PCR and barcoding ( $15 \mu \mathrm{L}$ volume) were performed as described in Jiménez et al. [39]. Barcoded samples were purified using NucleoMag NGS Beads (Macherey-Nagel, Düren, Germany) and quantified with picogreen on Tecan F200. Then, we pooled all samples to an equal amount of $12 \mathrm{ng}$ of DNA and diluted the pool down to $6 \mathrm{nM}$. Finally, the pooled sample library was paired-end sequenced in a single run on an Illumina MiSeq platform at the Institute of Evolutionary Ecology and Conservation Genomics, Ulm University, Germany. Raw sequence data were deposited into NCBI Repository, BioProject ID PRJNA703661.

\subsection{Bioinformatics}

The initial processing of the sequences was performed using QIIME 2 (version 2019.1) as described in Jiménez et al. [39]. For dada2 analysis, we trimmed the first bases of each read to remove primers (-p-trim-left-f $23,-p$-trim-left-r 20) and truncated forward and reverse reads to $200 \mathrm{bp}$ due to decreasing average quality scores of the sequences at the end. We collapsed reads into amplicon sequence variants (ASVs) and assigned bacterial taxonomy using the Greengenes database (version 13_8) as reference (http: / / greengenes.lbl.gov; accessed on 30 November 2020). We removed sequences classified as chloroplast, mitochondria, archaea, eukaryota, and unclassified phylum. We built a phylogenetic tree of the bacterial ASVs for further diversity analyses using MAFFT [45] and Fast Tree 2 [46]. Then, we imported our data into the R environment version 3.6.3 (https: / / www.r-project.org/; accessed on 30 November 2020) for further processing of the sequences using the R pack- 
age "phyloseq" [47]. We removed ASVs with less than 20 reads in the entire dataset and excluded samples with fewer than 9000 sequences. The resulting mean library size across individuals was 18,597 reads (range 9415-43,854). For alpha and beta diversity analyses, we rarefied the ASV table according to the sample with the lowest number of reads.

\subsection{Statistical Analysis in R Environment}

Because we used methanol as a carrier solvent, we first compared the negative control to the solvent control to detect statistical differences in alpha and beta diversity. We did not detect significant differences between negative and solvent controls considering the three alpha diversity measures (ASV richness: $p=0.94$, Shannon diversity index: $p=0.97$ and PD: $p=0.95$; Figure S1). However, we observed that beta diversity differed between negative and solvent controls based on the ASV presence-absence composition (unweighted UniFrac: $R^{2}=0.05 ; p=0.040$ ) and the ASV abundance-weighted composition (Bray-Curtis: $\mathrm{R}^{2}=0.12 ; p=0.001$ ) (Figure $\mathrm{S} 2$ ). Thus, the solvent control was used as the basis of comparison in further analysis.

To investigate the effect of chlorothalonil treatments on the skin bacterial alpha diversity measures (ASV richness, Shannon diversity index, and phylogenetic diversity (PD)), we used Generalized Linear Models (GLMs) with Gaussian distribution. We log-transformed the alpha diversity measures prior to model fitting.

To examine the effect of chlorothalonil treatments on skin bacterial beta diversity, we calculated the unweighted UniFrac (based on ASV absence/presence) and Bray-Curtis dissimilarity (based on abundance pattern of ASV) metrics using the R package "phyloseq". We fitted permutational multivariate analyses of variance (PERMANOVAs) using the adonis function of the R package "vegan" [48] to statistically test the effect of fungicide treatments on both beta diversity metrics. We performed permutational pairwise post-hoc tests with a Bonferroni correction to evaluate statistical differences of bacterial beta diversity between chlorothalonil treatments and solvent control. Additionally, we quantified the extent of the difference between group centroids (treatments) as a measure of effect size by calculating Cohen's d and 95\% CI with the R package "compute.es" [49]. We performed principal coordinate analysis (PCoA) to visualize the beta diversity distances between treatments.

Then, to identify ASVs that were significantly suppressed or overabundant in the two fungicide treatments, we used a negative binomial model-based approach (exact binomial test generalized for overdispersed counts) using the R package "edgeR" [50]. We present only ASVs that differed significantly between fungicide treatments and solvent control (FDR-corrected $p$-values at $p<0.001$ ). We used the unrarefied dataset and the Trimmed Mean of M-values (TMM) method for the normalization of samples. Additionally, we explored the presence of putative Bd-inhibitory bacteria being suppressed or overabundant from the results of the previous analysis. To identify the putative Bd-inhibitory ASVs, we queried our ASV sequences against a database of culturable anti-Bd bacteria identified from different amphibian species (Antifungal Isolates Database; [51]). We retained ASVs with a $\geq 99 \%$ sequence identity match to those in the mentioned database following the methods outlined by Muletz-Wolz et al. [52] with the software Geneious version 20.1.2.

\section{Results}

\subsection{Chlorothalonil Disturbs the Skin Microbiome Beta Diversity}

We did not detect a significant effect of chlorothalonil treatments on the three alpha diversity measures (ASV richness: $p=0.90$, Shannon diversity index: $p=0.90$, and PD: $p=0.33$; Figure S1). The PERMANOVA models revealed a significant effect of treatments on the ASV presence-absence composition (unweighted UniFrac: $\mathrm{R}^{2}=0.09, p=0.02$, Figure 1a) and the ASV abundance-weighted composition (Bray-Curtis dissimilarity: $\mathrm{R}^{2}=0.09, p=0.004$, Figure $1 \mathrm{~b}$ ). Pairwise PERMANOVA tests indicated significant differences in the bacterial community composition between the tadpoles kept in the solvent control and the treatment with a high concentration of the fungicide, whereas those between solvent control and the treatment with a low concentration were similar (Table 1). 
Pairwise PERMANOVA tests and Cohen's $\mathrm{d}$ effect sizes showed that the $\mathrm{R}^{2}$ and effect sizes between tadpoles of the solvent control and the high-concentration treatment were higher than between tadpoles of the solvent control and the low-concentration treatment, indicating a greater difference in the higher concentration of fungicide (Table 1). Furthermore, skin bacterial communities of tadpoles exposed to a high concentration of fungicide clustered more distantly from solvent control treatment on the PCoA than those exposed to a low concentration of fungicide (Figure 1a,b).
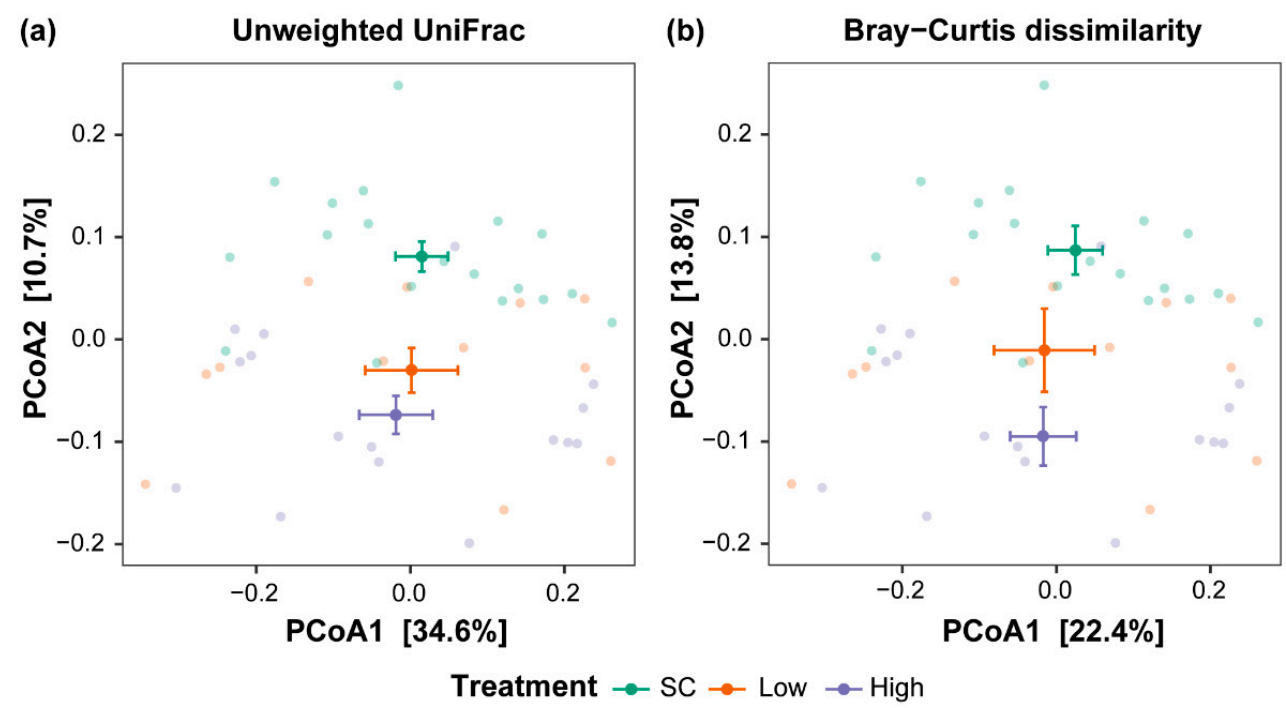

Figure 1. Principal coordinate analysis (PCoA) of skin bacterial communities of tadpoles exposed to chlorothalonil based on (a) unweighted UniFrac and (b) Bray-Curtis dissimilarity. Points represent the centroid for each treatment group with an indication of standard errors on each coordinate axis. Colors distinguish the different treatments, and each transparent point represents the skin bacterial community of an individual sample. SC = solvent control.

Table 1. Pairwise comparisons of beta diversity skin microbiota of tadpoles in response to chlorothalonil.

\begin{tabular}{cccccc}
\hline Beta Diversity Metric & Comparison & $\mathbf{R}^{2}$ & $p$-Value & Adjusted $p$-Value & Cohen's d \\
\hline \multirow{3}{*}{\begin{tabular}{c} 
Unweighted UniFrac \\
\cline { 2 - 6 }
\end{tabular}} & SC vs. Low & 0.06 & 0.07 & 0.21 & $0.61(-0.15,1.39)$ \\
\cline { 2 - 6 } & SC vs. High & 0.09 & 0.01 & $0.02 *$ & $0.89(0.17,1.62)$ \\
\cline { 2 - 6 } $\begin{array}{c}\text { Bray-Curtis } \\
\text { dissimilarity }\end{array}$ & Low vs. High & 0.04 & 0.30 & 0.90 & $0.23(-0.55,1.02)$ \\
\cline { 2 - 6 } & SC vs. Low & 0.04 & 0.16 & $0.003 *$ & $0.98(0.25,1.71)$ \\
\hline & SC vs. High & 0.10 & 0.001 & 0.35 & $0.37(-0.42,1.17)$ \\
\hline
\end{tabular}

\subsection{Chlorothalonil Shifts Relative Abundance of Bacterial Strains}

We detected that ASVs differed significantly between fungicide treatments and SC (Figure 2a,b). We found three ASVs suppressed when tadpoles were exposed to a low concentration of chlorothalonil, and 14 ASVs showed an increased abundance (Figure 2a). Tadpoles exposed to a high concentration of chlorothalonil showed 13 suppressed ASVs and seven overrepresented (Figure 2b). Tadpoles exposed to a high concentration had a higher number of bacterial taxa with reduced abundance than those exposed to a low concentration of fungicide. In both treatments, a low and high concentration of chlorothalonil, tadpoles showed a significant decrease in abundance for ASVs of the genera Sulfuricurvum and Janthinobacterium, whereas an abundance increment was observed for ASVs of the genera Nevskia, Flavobacterium, and Runella. We identified four putative Bd-inhibitory ASVs with significantly lower abundance in tadpoles exposed to chlorothalonil, one in 
tadpoles exposed to a low concentration and four in those exposed to a high concentration (Figure 2a,b). These putative Bd-inhibitory ASVs were assigned to the family Comamonadaceae and the genus Janthinobacterium, Acinetobacter, and Novosphingobium.
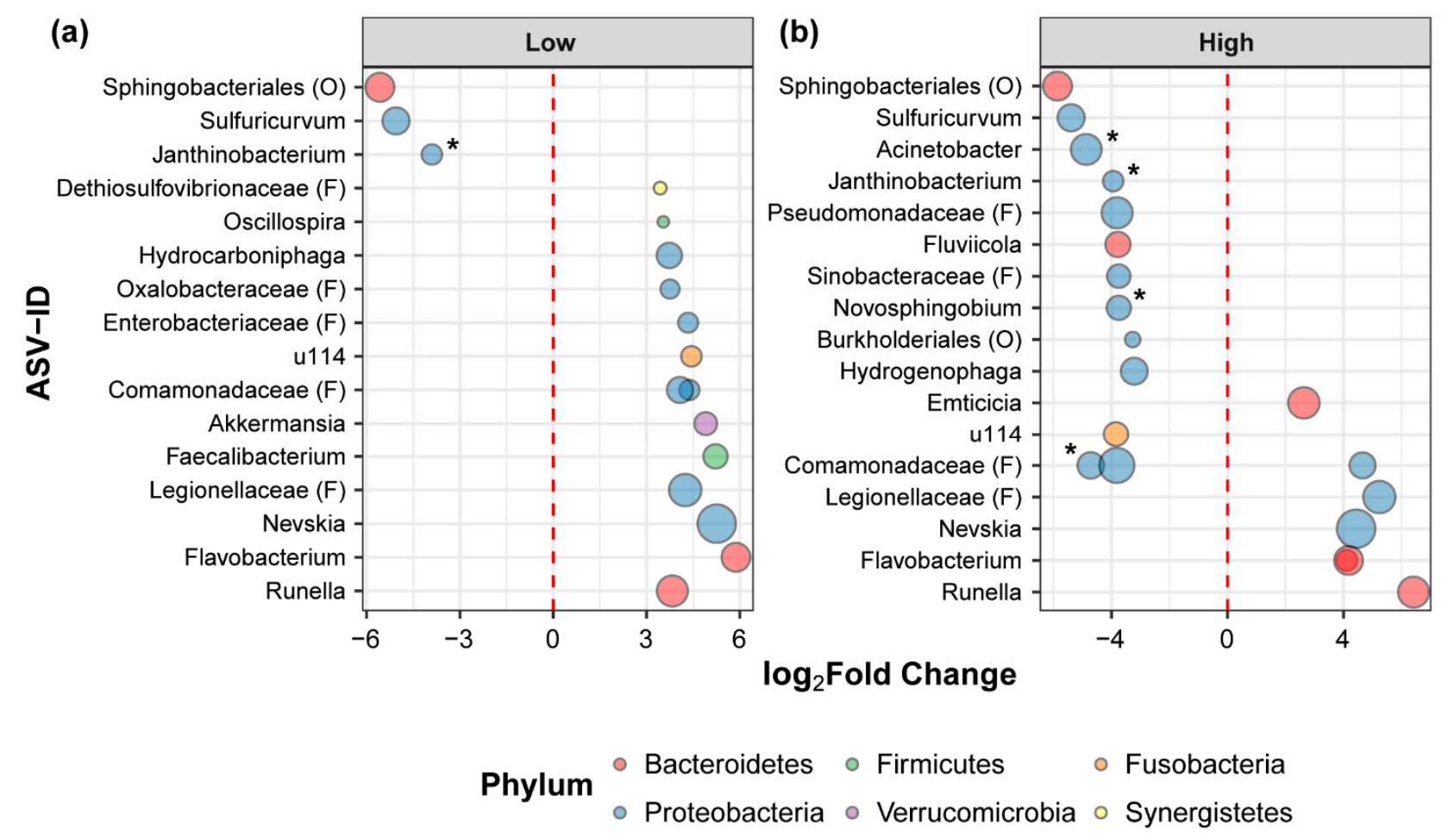

Figure 2. Differential abundance of ASVs in relation to exposure to (a) low and (b) high chlorothalonil concentrations. Taxa below zero line are significantly suppressed. The ASVs are colored by phylum and sized by mean relative abundance across samples. The highest possible taxonomic assignment (maximal to the genus level) is shown for each ASV. Letters in parenthesis represent taxonomic classification: $\mathrm{O}=$ order, $\mathrm{F}=$ family. Asterisks denote ASVs that were taxonomically similar ( $\geq 99 \%$ sequence similarity) to known Bd-inhibitory bacteria.

\section{Discussion}

The present study highlights the impact of chlorothalonil, a widely used fungicide, on the immunologically important skin microbial community of a threatened frog that persists despite ongoing exposure to $\mathrm{Bd}$. We provide evidence that exposure to chlorothalonil changes the skin bacterial community of tadpoles of L. vibicarius and, even more importantly, that chlorothalonil can suppress putative Bd-inhibitory bacterial strains at high concentrations. These results raise new concerns and hypotheses that need to be addressed to have a broader understanding of the impact of fungicides on the protective relationship between skin microbiomes and amphibian hosts.

Our results show that the skin bacterial community differed when tadpoles were exposed to higher concentrations of chlorothalonil. The effect sizes on beta diversity indicated that differences in bacterial communities of tadpoles increased as animals were exposed to higher concentrations of the fungicide. These findings indicate a change, and potential disruption, of skin bacterial communities as the concentration of chlorothalonil increases. Given that the microbiome can play a role in host health maintenance and that disruption of the natural range of microbial communities may lead to increased incidence of diseases in their hosts $[15,53,54]$, our results suggest that exposure to chlorothalonil may increase susceptibility to diseases. Further work is needed to corroborate these hypotheses. A previous study found an alteration of the skin bacterial communities of tadpoles of Blanchard's cricket frog (Acris blanchardi, family Hylidae) when exposed to an herbicide [55]. Together, these studies suggest that changes in bacterial communities occur with a distinct type of pesticides and highlight an interest in investigating how pesticide 
mixtures (for example, a mixture of fungicides and herbicides) could be interacting to impact the function of microbial communities of amphibians.

Previous studies indicate that microbial communities are among the first taxa to respond to chemicals exposure [56-58]. Chlorothalonil could be directly and/or indirectly interacting with the skin bacteria of L. vibicarius tadpoles by altering their cutaneous bacterial communities. Microorganisms are functionally or nutritionally connected to each other, and changes in one component of a microbial community (e.g., the fungal community (mycobiome)) can influence the structure of the entire community [59-61]. Therefore, the fungicide chlorothalonil could be changing the skin mycobiome and thereby influencing the observed changes in the bacterial communities. In this study, we did not evaluate the skin mycobiome, so further research investigating interactions between fungal and bacterial communities after chlorothalonil exposure will provide broader insight into the impact of this fungicide on host-associated microbial communities. In addition, chlorothalonil could be affecting tadpoles' physiology, endocrine, and immune systems, as previously observed in different amphibian species [34], indirectly altering the host bacterial communities through different mechanisms. Here, we have not evaluated the host physiology mechanisms that could be changing these communities. However, we suspect that chlorothalonil could be contributing to an increment of stress on exposed individuals, as observed in tadpoles of the Cuban tree frog Osteopilus septentrionalis (family Hylidae) [34], thus affecting the tadpoles' skin bacterial community and resulting in a potential detriment of the host immune defenses. It is also possible that chlorothalonil may have interfered with the host skin peptide secretions that act as a selective force that controls which microbes can grow on each host's skin. The properties of the skin peptides have been shown to be affected by exposure to the insecticide carbaryl in yellow-footed frogs (Rana boylii, family Ranidae) [62]. These potential alterations to the skin properties by chlorothalonil may have disrupted the appropriate conditions for some bacteria to grow, consequently suppressing their abundance and altering host microbial communities. Further research is needed to investigate these potential mechanisms and will provide a better understanding of the impact of chlorothalonil on an amphibian immune defense trait.

We found different patterns in the relative abundances of bacterial taxa across chlorotha lonil treatments. We also observed the suppression of some putative Bd-inhibitory bacterial strains (for example, strains of genus Janthinobacterium and Acinetobacter) when exposed to chlorothalonil, particularly in the high-concentration treatment. These protective bacteria are known to be capable of producing metabolites that suppress Bd infections $[10,11,63]$. Together, this suggests that changes in bacterial abundances from chlorothalonil exposure could be disrupting the adequate production of defensive bacterial metabolites that facilitate disease resistance. Further, the suppression of some Bd-inhibitory bacteria provides evidence that chlorothalonil can interfere with these protective taxa, highlighting a potential risk in the disruption of host susceptibility to chytrid infections in early and/or later life stages. This knowledge is relevant as a reduction in bacterial abundances could represent the loss of key bacterial species and functions linked to host health. Previous evidence suggests that amphibian larval stages that have been exposed to chlorothalonil have higher Bd intensity and greater Bd-induced mortality when challenged with Bd after metamorphosis [36]. Therefore, exposure to chlorothalonil in early life might alter the normal bacterial community that establishes a healthy and Bd-protective skin microbiome after metamorphosis, making exposed animals vulnerable to future Bd infections. Based on this information, it would be interesting to investigate if this early-life disruption of bacterial abundances has lasting impacts on host $\mathrm{Bd}$ resistance later in life. It is also possible that opportunistic microbes and/or parasites with tolerance to chlorothalonil increase their abundance altering the natural microbial structure. Addressing this gap in our knowledge will allow a better understanding of the development of the immune system and will provide information that will help prevent early disruption of host microbiomes to confer better protection against diseases, such as chytridiomycosis. 
We observed some individuals in the high-concentration treatment showing reddish skin, suggesting some type of external dermatitis probably attributed to the fungicide exposure. This is an interesting observation to highlight from our study because skin irritation has been linked to chlorothalonil exposure in animals [64]. This is merely an observation during our experiment but brings out the need for further investigation because chlorothalonil exposure has been associated with skin irritation and contact dermatitis in humans [65-67]. Atopic dermatitis can also allow for the colonization of certain types of bacteria that trigger immune response such as inflammation that can worsen symptoms and jeopardize host health [68].

Our understanding of how pesticides influence the amphibian microbiome is still in its infancy [16]. Our study reveals the effect of the exposure to environmentally relevant concentrations of the fungicide chlorothalonil on the skin microbiomes of amphibians in the early-life stage, which may, in turn, impact the stability of host-microbe interactions and microbiome-fitness correlations. Further studies are desperately needed, so we can fully understand the interaction between pesticides, the disease-causing organisms, and how these effects scale up to play a role in amphibian disease dynamics.

Supplementary Materials: The following are available online at https:/ / www.mdpi.com/article/10 .3390/applmicrobiol1010004/s1, Figure S1: Alpha diversity metrics of skin bacterial communities of tadpoles exposed to chlorothalonil, Figure S2: Principal coordinate analysis (PCoA) of skin bacterial communities of tadpoles kept in water and solvent controls, Table S1: Physicochemical parameters measured in water and solvent controls, and chlorothalonil treatments. Table S2: Sample size of tadpoles per experimental treatment.

Author Contributions: Conceptualization, R.R.J. and S.S.; methodology, R.R.J., S.S., G.A., C.R. and E.B; software, R.R.J.; validation, R.R.J., S.S., G.A., C.R. and E.B.; formal analysis, R.R.J. and S.S.; investigation, R.R.J., S.S., G.A., C.R. and E.B.; resources, S.S., G.A. and C.R.; data curation, R.R.J.; writing-original draft preparation, R.R.J. and S.S.; writing—review and editing, R.R.J., S.S., G.A., C.R. and E.B.; visualization, R.R.J.; supervision, R.R.J. and S.S.; project administration, R.R.J. and S.S.; funding acquisition, R.R.J. and S.S. All authors have read and agreed to the published version of the manuscript.

Funding: This research was funded by start-up funding to S.S. by the University of Ulm and by the National Council for Scientific and Technological Research of Costa Rica and the Ministry of Science and Technology of Costa Rica to R.R.J.

Institutional Review Board Statement: This study and ethical procedures were approved by National Commission for the Biodiversity Management of Costa Rica (R-057-2019-OT-CONAGEBIO) and the Ministry of Environment and Energy of Costa Rica-National System of Conservation Areas (SINAC-ACAHN-PI-R-010-2017).

Informed Consent Statement: Not applicable.

Data Availability Statement: All raw sequence data were deposited into NCBI Repository, BioProject ID PRJNA703661.

Acknowledgments: We thank Tania Chacon, Kimberly Castro, and Michael Méndez for logistical assistance with the study. We are grateful to Luis Víquez, Alexander Heni, and especially Kerstin Wilhelm for technical and laboratory assistance. We thank Allison Byrne for scientific input and language corrections.

Conflicts of Interest: The authors declare no conflict of interest. The funders had no role in the design of the study; in the collection, analyses, or interpretation of data; in the writing of the manuscript, or in the decision to publish the results. 


\section{References}

1. Densmore, C.L.; Green, D.E. Diseases of amphibians. ILAR J. 2007, 48, 235-254. [CrossRef]

2. Bower, D.S.; Lips, K.R.; Schwarzkopf, L.; Georges, A.; Clulow, S. Amphibians on the brink. Science 2017, 357, 454-455. [CrossRef] [PubMed]

3. Scheele, B.C.; Skerratt, L.F.; Grogan, L.F.; Hunter, D.A.; Clemann, N.; McFadden, M.; Newell, D.; Hoskin, C.J.; Gillespie, G.R.; Heard, G.W.; et al. After the epidemic: Ongoing declines, stabilizations and recoveries in amphibians afflicted by chytridiomycosis. Biol. Conserv. 2017, 206, 37-46. [CrossRef]

4. Rollins-Smith, L.A. Global amphibian declines, disease, and the ongoing battle between Batrachochytrium fungi and the immune system. Herpetologica 2020, 76, 178-188. [CrossRef]

5. Briggs, C.J.; Knapp, R.A.; Vredenburg, V.T. Enzootic and epizootic dynamics of the chytrid fungal pathogen of amphibians. Proc. Natl. Acad. Sci. USA 2010, 107, 9695-9700. [CrossRef] [PubMed]

6. Martel, A.; der Sluijs, A.S.; Blooi, M.; Bert, W.; Ducatelle, R.; Fisher, M.C.; Woeltjes, A.; Bosman, W.; Chiers, K.; Bossuyt, F.; et al. Batrachochytrium salamandrivorans sp. nov. causes lethal chytridiomycosis in amphibians. Proc. Natl. Acad. Sci. USA 2013, 201307356. [CrossRef] [PubMed]

7. Grice, E.A.; Segre, J.A. The skin microbiome. Nat. Rev. Micro. 2011, 9, 244-253. [CrossRef]

8. McLaren, M.R.; Callahan, B.J. Pathogen resistance may be the principal evolutionary advantage provided by the microbiome. Philos. Trans. R. Soc. B. Biol. Sci. 2020, 375, 20190592. [CrossRef]

9. Rebollar, E.A.; Martínez-Ugalde, E.; Orta, A.H. The amphibian skin microbiome and its protective role against chytridiomycosis. Herpetologica 2020, 76, 167-177. [CrossRef]

10. Becker, M.H.; Brucker, R.M.; Schwantes, C.R.; Harris, R.N.; Minbiole, K.P.C. The bacterially produced metabolite violacein is associated with survival of amphibians infected with a lethal fungus. Appl. Environ. Microbiol. 2009, 75, 6635-6638. [CrossRef]

11. Harris, R.N.; Brucker, R.M.; Walke, J.B.; Becker, M.H.; Schwantes, C.R.; Flaherty, D.C.; Lam, B.A.; Woodhams, D.C.; Briggs, C.J.; Vredenburg, V.T.; et al. Skin microbes on frogs prevent morbidity and mortality caused by a lethal skin fungus. ISME J. 2009, 3, 818-824. [CrossRef]

12. Piovia-Scott, J.; Rejmanek, D.; Woodhams, D.C.; Worth, S.J.; Kenny, H.; McKenzie, V.; Lawler, S.P.; Foley, J.E. Greater species richness of bacterial skin symbionts better suppresses the amphibian fungal pathogen Batrachochytrium dendrobatidis. Microb. Ecol. 2017, 74, 217-226. [CrossRef]

13. Rebollar, E.A.; Bridges, T.; Hughey, M.C.; Medina, D.; Belden, L.K.; Harris, R.N. Integrating the role of antifungal bacteria into skin symbiotic communities of three neotropical frog species. ISME J. 2019, 13, 1763-1775. [CrossRef] [PubMed]

14. West, A.G.; Waite, D.W.; Deines, P.; Bourne, D.G.; Digby, A.; McKenzie, V.J.; Taylor, M.W. The microbiome in threatened species conservation. Biol. Conserv. 2019, 229, 85-98. [CrossRef]

15. Jiménez, R.R.; Sommer, S. The amphibian microbiome: Natural range of variation, pathogenic dysbiosis, and role in conservation. Biodivers. Conserv. 2017, 26, 763-786. [CrossRef]

16. McCoy, K.A.; Peralta, A.L. Pesticides could alter amphibian skin microbiomes and the effects of Batrachochytrium dendrobatidis. Front. Microbiol. 2018, 9. [CrossRef]

17. Paris, L.; Peghaire, E.; Moné, A.; Diogon, M.; Debroas, D.; Delbac, F.; El Alaoui, H. Honeybee gut microbiota dysbiosis in pesticide/parasite co-exposures is mainly induced by Nosema ceranae. J. Invertebr. Pathol. 2020, 172, 107348. [CrossRef] [PubMed]

18. Daly, G.L.; Lei, Y.D.; Teixeira, C.; Muir, D.C.G.; Castillo, L.E.; Wania, F. Accumulation of current-use pesticides in neotropical montane forests. Environ. Sci. Technol. 2007, 41, 1118-1123. [CrossRef]

19. Zubrod, J.P.; Bundschuh, M.; Arts, G.; Brühl, C.A.; Imfeld, G.; Knäbel, A.; Payraudeau, S.; Rasmussen, J.J.; Rohr, J.; Scharmüller, A.; et al. Fungicides: An overlooked pesticide class? Environ. Sci. Technol. 2019, 53, 3347-3365. [CrossRef] [PubMed]

20. Kakumanu, M.L.; Reeves, A.M.; Anderson, T.D.; Rodrigues, R.R.; Williams, M.A. Honey bee gut microbiome is altered by in-hive pesticide exposures. Front. Microbiol. 2016, 7. [CrossRef]

21. Kohl, K.D.; Cary, T.L.; Karasov, W.H.; Dearing, M.D. Larval exposure to polychlorinated biphenyl 126 (PCB-126) causes persistent alteration of the amphibian gut microbiota. Environ. Toxicol. Chem. 2015, 34, 1113-1118. [CrossRef]

22. Sigler, W.V.; Turco, R.F. The impact of chlorothalonil application on soil bacterial and fungal populations as assessed by denaturing gradient gel electrophoresis. Appl. Soil Ecol. 2002, 21, 107-118. [CrossRef]

23. Baćmaga, M.; Wyszkowska, J.; Kucharski, J. The influence of chlorothalonil on the activity of soil microorganisms and enzymes. Ecotoxicology 2018, 27, 1188-1202. [CrossRef]

24. Raman, P. Chlorothalonil. In Encyclopedia of Toxicology, 3rd ed.; Wexler, P., Ed.; Academic Press: Oxford, UK, 2014.

25. Chaves, A.; Shea, D.; Cope, W.G. Environmental fate of chlorothalonil in a costa rican banana plantation. Chemosphere 2007, 69, 1166-1174. [CrossRef]

26. Castillo, L.E.; Ruepert, C.; Solis, E. Pesticide residues in the aquatic environment of banana plantation areas in the North Atlantic zone of Costa Rica. Environ. Toxicol. Chem. 2000, 19, 1942-1950. [CrossRef]

27. Caux, P.-Y.; Kent, R.A.; Fan, G.T.; Stephenson, G.L. Environmental fate and effects of chlorothalonil: A canadian perspective. Crit. Rev. Env. Sci. Technol. 1996, 26, 45-93. [CrossRef]

28. Tillman, R.W.; Siegel, M.R.; Long, J.W. Mechanism of action and fate of the fungicide chlorothalonil (2,4,5,6-tetrachloroisophthalonitrile) in biological systems: I. Reactions with cells and subcellular components of Saccharomyces pastorianus. Pestic. Biochem. Phys. 1973, 3, 160-167. [CrossRef] 
29. Callicott, K.; Hooper-Bùi, L. An investigation of environmental concentrations of atrazine, chlorothalonil, and fipronil in a Mississippi river-influenced marsh in Southern Louisiana. Microchem. J. 2019, 146, 1241-1248. [CrossRef]

30. Datta, S.; Hansen, L.; McConnell, L.; Baker, J.; LeNoir, J.; Seiber, J.N. Pesticides and PCB contaminants in fish and tadpoles from the Kaweah River Basin, California. Bull. Environ. Contam. Toxicol. 1998, 60, 829-836. [CrossRef]

31. Smalling, K.L.; Reeves, R.; Muths, E.; Vandever, M.; Battaglin, W.A.; Hladik, M.L.; Pierce, C.L. Pesticide concentrations in frog tissue and wetland habitats in a landscape dominated by agriculture. Sci. Total Environ. 2015, 502, 80-90. [CrossRef]

32. Acquaroni, M.; Svartz, G.; Pérez Coll, C. Developmental toxicity asessment of a chlorothalonil-based fungicide in a native amphibian species. Arch. Environ. Contam. Toxicol. 2020. [CrossRef]

33. Yu, S.; Wages, M.R.; Cobb, G.P.; Maul, J.D. Effects of chlorothalonil on development and growth of amphibian embryos and larvae. Environ. Pollut. 2013, 181, 329-334. [CrossRef]

34. McMahon, T.A.; Halstead, N.T.; Johnson, S.; Raffel, T.R.; Romansic, J.M.; Crumrine, P.W.; Boughton, R.K.; Martin, L.B.; Rohr, J.R. The fungicide chlorothalonil is nonlinearly associated with corticosterone levels, immunity, and mortality in amphibians. Environ. Health Perspec. 2011, 119, 1098-1103. [CrossRef]

35. Méndez, M.; Obando, P.; Pinnock-Branford, M.; Ruepert, C.; Castillo, L.E.; Mena, F.; Alvarado, G. Acute, chronic and biochemical effects of chlorothalonil on Agalychnis callidryas, Isthmohyla pseudopuma and Smilisca baudinii tadpoles. Environ. Sci. Pollut. Res. Int. 2016, 23, 21238-21248. [CrossRef]

36. Rohr, J.R.; Brown, J.; Battaglin, W.A.; McMahon, T.A.; Relyea, R.A. A pesticide paradox: Fungicides indirectly increase fungal infections. Ecol. Appl. 2017, 27, 2290-2302. [CrossRef]

37. Savage, J.M. The Amphibians and Reptiles of Costa Rica: A Herpetofauna between Two Continents, between Two Seas; The University of Chicago Press: Chicago, IL, USA, 2002.

38. Whitfield, S.M.; Alvarado, G.; Abarca, J.; Zumbado, H.; Zuñiga, I.; Wainwright, M.; Kerby, J. Differential patterns of Batrachochytrium dendrobatidis infection in relict amphibian populations following severe disease-associated declines. Dis. Aquat. Org. 2017, 126, 33-41. [CrossRef] [PubMed]

39. Jiménez, R.R.; Alvarado, G.; Estrella, J.; Sommer, S. Moving beyond the host: Unraveling the skin microbiome of endangered costa rican amphibians. Front. Microbiol. 2019, 10. [CrossRef] [PubMed]

40. Gabor, C.R.; Knutie, S.A.; Roznik, E.A.; Rohr, J.R. Are the adverse effects of stressors on amphibians mediated by their effects on stress hormones? Oecologia 2018, 186, 393-404. [CrossRef]

41. Harrison, X.A.; Price, S.J.; Hopkins, K.; Leung, W.T.M.; Sergeant, C.; Garner, T.W.J. Diversity-stability dynamics of the amphibian skin microbiome and susceptibility to a lethal viral pathogen. Front. Microbiol. 2019, 10. [CrossRef] [PubMed]

42. Bataille, A.; Lee-Cruz, L.; Tripathi, B.; Kim, H.; Waldman, B. Microbiome variation across amphibian skin regions: Implications for chytridiomycosis mitigation efforts. Microb. Ecol. 2015. [CrossRef] [PubMed]

43. Córdoba Gamboa, L.; Solano Diaz, K.; Ruepert, C.; van Wendel de Joode, B. Passive monitoring techniques to evaluate environmental pesticide exposure: Results from the infant's environmental health study (ISA). Environ. Res. 2020, 184, 109243. [CrossRef] [PubMed]

44. Grabuski, J. Pesticides in Ontario: A Critical Assessment of Potential Toxicity of Urban Use Products to Wildlife, with Consideration for Endocrine Disruption. Volume 3: Phenoxy Herbicides, Chlorothalonil and Chlorpyrifos; Technical Report Series No. 410; Environment Canada: Dufferin Downsview, ON, Canada.

45. Katoh, K.; Standley, D.M. MAFFT Multiple sequence alignment software version 7: Improvements in performance and usability. Mol. Biol. Evol. 2013, 30, 772-780. [CrossRef] [PubMed]

46. Price, M.N.; Dehal, P.S.; Arkin, A.P. FastTree 2-Approximately maximum-likelihood trees for large alignments. PLoS ONE 2010, 5, e9490. [CrossRef] [PubMed]

47. McMurdie, P.J.; Holmes, S. Phyloseq: An R package for reproducible interactive analysis and graphics of microbiome census data. PLoS ONE 2013, 8, e61217. [CrossRef]

48. Oksanen, J.; Guillaume, B.F.; Kindt, R.; Legendre, P.; Minchin, P.R.; O’Hara, R.B.; Simpson, G.L.; Solymos, P.; Henry, M.; Stevens, M.H.; et al. Vegan: Community Ecology Package, R Package Version 2.5-4. 2019.

49. Del Re, A.C. Compute.es: Compute Effect Sizes, R Package Version 0.2-2. 2013.

50. Robinson, M.D.; McCarthy, D.J.; Smyth, G.K. EdgeR: A Bioconductor package for differential expression analysis of digital gene expression data. Bioinformatics 2010, 26, 139-140. [CrossRef]

51. Woodhams, D.C.; Alford, R.A.; Antwis, R.E.; Archer, H.; Becker, M.H.; Belden, L.K.; Bell, S.C.; Bletz, M.; Daskin, J.H.; Davis, L.R.; et al. Antifungal isolates database of amphibian skin-associated bacteria and function against emerging fungal pathogens. Ecology 2015, 96, 595. [CrossRef]

52. Muletz-Wolz, C.R.; Fleischer, R.C.; Lips, K.R. Fungal disease and temperature alter skin microbiome structure in an experimental salamander system. Mol. Ecol. 2019, 28, 2917-2931. [CrossRef]

53. Zaneveld, J.R.; McMinds, R.; Vega Thurber, R. Stress and stability: Applying the Anna Karenina Principle to animal microbiomes. Nat. Microbiol. 2017, 2, 17121. [CrossRef]

54. Bletz, M.C.; Kelly, M.; Sabino-Pinto, J.; Bales, E.; Van Praet, S.; Bert, W.; Boyen, F.; Vences, M.; Steinfartz, S.; Pasmans, F.; et al. Disruption of skin microbiota contributes to salamander disease. Proc. R. Soc. B Biol. Sci. 2018, 285, 20180758. [CrossRef] [PubMed]

55. Krynak, K.L.; Burke, D.J.; Benard, M.F. Rodeo ${ }^{\mathrm{TM}}$ herbicide negatively affects blanchard's cricket frogs (Acris blanchardi) survival and alters the skin-associated bacterial community. J. Herpetol. 2017, 51, 402-410. [CrossRef] 
56. Downing, H.F.; DeLorenzo, M.E.; Fulton, M.H.; Scott, G.I.; Madden, C.J.; Kucklick, J.R. Effects of the agricultural pesticides atrazine, chlorothalonil, and endosulfan on South Florida microbial assemblages. Ecotoxicology 2004, 13, $245-260$. [CrossRef] [PubMed]

57. Hussain, S.; Siddique, T.; Saleem, M.; Arshad, M.; Khalid, A. Chapter 5: Impact of pesticides on soil microbial diversity, enzymes, and biochemical reactions. In Advances in Agronomy; Academic Press: Cambridge, MA, USA, 2009; Volume 102, pp. 159-200.

58. Imfeld, G.; Vuilleumier, S. Measuring the effects of pesticides on bacterial communities in soil: A critical review. Eur. J. Soil Biol. 2012, 49, 22-30. [CrossRef]

59. Oever, J.T.; Netea, M.G. The bacteriome-mycobiome interaction and antifungal host defense. Eur. J. Immunol. 2014, 44, 3182-3191. [CrossRef]

60. Chin, V.K.; Yong, V.C.; Chong, P.P.; Amin Nordin, S.; Basir, R.; Abdullah, M. Mycobiome in the gut: A multiperspective review. Mediat. Inflamm. 2020, 2020, e9560684. [CrossRef] [PubMed]

61. Yang, C.; Hamel, C.; Vujanovic, V.; Gan, Y. Fungicide: Modes of action and possible impact on nontarget microorganisms. ISRN Ecol. 2011, 2011, e130289. [CrossRef]

62. Davidson, C.; Benard, M.F.; Shaffer, H.B.; Parker, J.M.; O'Leary, C.; Conlon, J.M.; Rollins-Smith, L.A. Effects of chytrid and carbaryl exposure on survival, growth and skin peptide defenses in foothill yellow-legged frogs. Environ. Sci. Technol. 2007, 41, 1771-1776. [CrossRef] [PubMed]

63. Becker, M.H.; Harris, R.N. Cutaneous bacteria of the redback salamander prevent morbidity associated with a lethal disease. PLoS ONE 2010, 5, e10957. [CrossRef]

64. Parsons, P.P. Chapter 91-Mammalian toxicokinetics and toxicity of chlorothalonil. In Hayes' Handbook of Pesticide Toxicology, 3rd ed.; Krieger, R., Ed.; Academic Press: New York, NY, USA, 2010; pp. 1951-1966. ISBN 978-0-12-374367-1.

65. Penagos, H.G. Contact dermatitis caused by pesticides among banana plantation workers in Panama. Int. J. Occup. Environ. Health 2002, 8, 14-18. [CrossRef]

66. Penagos, H.; Ruepert, C.; Partanen, T.; Wesseling, C. Pesticide patch test series for the assessment of allergic contact dermatitis among banana plantation workers in Panama. Dermatitis 2004, 15, 137-145. [CrossRef] [PubMed]

67. European Food Safety Authority (EFSA); Arena, M.; Auteri, D.; Barmaz, S.; Bellisai, G.; Brancato, A.; Brocca, D.; Bura, L.; Byers, H.; Chiusolo, A.; et al. Peer review of the pesticide risk assessment of the active substance chlorothalonil. EFSA J. 2018, 16, e05126. [CrossRef]

68. Baker, B.S. The Role of microorganisms in atopic dermatitis. Clin. Exp. Immunol. 2006, 144, 1-9. [CrossRef] [PubMed] 